\title{
SCREENING AND OPTIMIZATION OF THERMO-TOLERANT Bacillus sp. FOR AMYLASE PRODUCTION AND ANTIFUNGAL ACTIVITY
}

\author{
Susmita Sapkota ${ }^{1 \#}$, Sujan Khadka ${ }^{2}$, Aava Gautam ${ }^{1 \#}$, Rojina Maharjan $^{1 \#}$, Ruby Shah ${ }^{1 \#}$, Sandhya Dhakal ${ }^{1}$, Om \\ Prakash Panta, Santosh Khanal, Pramod Poudel ${ }^{1,3 *}$ \\ ${ }^{I}$ Department of Microbiology, National College (NIST), Tribhuvan University, Kathmandu, Nepal \\ ${ }^{2}$ Department of Microbiology, Birendra Multiple Campus, Tribhuvan University, Bharatpur, Chitwan, Nepal \\ ${ }^{3}$ Research Division, University Grant Commission (UGC), PO Box: 10796, Sanothimi, Bhaktapur, Nepal \\ *Corresponding author: poudel.pm@gmail.com
}

(Received: March 30, 2019; Revised: June 12, 2019; Accepted: June 18, 2019)

\begin{abstract}
Amylases are starch degrading enzymes which are produced by plants, animals and microorganisms. Amylases produced by microorganisms have a wide range of industrial applications such as in pharmaceutical, food, textile and paper industries. However, there are still limitations in the isolation of amylase producing microorganisms. The objective of this study was to isolate the potent amylase producing Bacillus sp. from soil samples and evaluate their abilities for inhibiting the aflatoxin producing Aspergillus flavus. In this study, 30 soil samples were used. For the screening and identification of Bacillus strain, morphological and biochemical tests were performed. Iodine assay was done to screen the potent amylase producers. Two parameters ( $\mathrm{pH}$ and temperature) were used to optimize the cultural conditions for the production of amylase. To determine the total reducing sugar, dinitrosalicylic acid (DNS) assay was used. Altogether 29 colonies were selected and identified as Bacillus spp out of which 16 were selected to determine enzyme activity by cup plate method. Four isolates (DK9, DK10, IM4 and KD7) showing highest amylolytic activities (16 mm, $12 \mathrm{~mm}, 14 \mathrm{~mm}$ and $14 \mathrm{~mm}$ zone of hydrolysis) were subjected for further study. Isolate KD7 showed the highest amylolytic activity $(0.19 \mathrm{U} / \mathrm{mL})$ compared to other isolates. Maximum amylase production was found at $\mathrm{pH} 6$ and temperature $50^{\circ} \mathrm{C}(0.19$ $\mathrm{U} / \mathrm{mL}$ ). Among these 4 isolates, DK9 and KD9 showed strong antagonistic activity against Aspergillus flavus while DK10 and IM4 showed moderate antifungal activities. Thus, the bacterial isolate KD7 was identified as the most potent strain for maximum amylase production.
\end{abstract}

Keywords: Soil, Thermotolerant Bacillus sp., Amylase producer, Aflatoxin producing A. flavus

\section{INTRODUCTION}

Geographical and climatic diversity in Nepal has unquestionably gifted to multiple biological diversities including thermotolerant soil microorganisms. Such microbial array is always a motivation for the scientific community to investigate for the remarkable microbial potency and of all; soil microbes showing amylolytic and antifungal activity are emphasized for their application in industrial and commericial purposes (Pokhrel et al. 2013). Amylases which degrade starch and related polymers to yield products characteristics of individual amylolytic enzymes, are the most significant industrial enzymes. Its great implication in biotechnology, constitutes a class of industrial enzymes having approximately 25-30\% of the world enzyme market (Azad et al. 2009, Aiyer 2005). Amylases can be obtained from several sources such as plant, animal and microbes amongst which microbial sources are the most preferred (Kathiresan \& Manivannan 2006). In industrial scale, exploitation of microorganisms for enzyme production is increasing and amylase productions and applications have almost entirely replaced chemical method of hydrolyzing starch in starch processing industry (Pandey et al. 2000). The major advantage of using microorganisms for production of amylases is economical bulk production and easy manipulation to obtain enzymes of desired characteristics (Aiyer 2005).

A large diversity of extracellular enzymes such as amylases, proteases, and lipases, with industrial importance are produced by Bacillus species (Cordeiro et al. 2002). Different Bacillus species produce different categories of amylases which vary in their feature (saccharifying or liquefying) and range of $\mathrm{pH}$ and temperature they thrive (Fossi et al. 2014). Thermotolerant Bacillus species are widely used for the production of amylases in different part of this globe and researchers exploited this group of bacteria for industrial amylase production (Afrisham et al. 2016). Thermotolerant microorganisms are those that are capable of growing in high temperature but can exhibit optimal growth under moderate conditions. Optimum condition for growth of microorganisms is influenced by $\mathrm{pH}$, temperature and other factors. At optimum $\mathrm{pH}$ and temperature microorganisms grow rapidly and produce large amount of enzymes.

Soil is one of the rich sources of starch degrading bacteria. Amylase stable to higher temperature are known to have commercial application in textile desizing, fermentation, 
food and paper industry (Lin et al. 1997). The capacity of Bacillus strains to produce large quantities of enzymes has placed them among the most important industrial enzyme producer. They produce about $60 \%$ of commercially available enzymes (Burhan et al. 2003). Bacterial enzymes are found in acidophilic, alkalophilic and acidothermophilic bacteria (Boyer \& Ingle 1972). Nowadays, amylase from bacterial sources is widely used in amylase production under extreme conditions of $\mathrm{pH}$ and temperature. There are various reports on starch degrading bacteria from different sources and respective amylase activity (Aiba et al. 1983).

Apart from the highly useful amylase Bacillus spp. are known for their antagonistic activity against potential harmful fungi and their mycotoxins which are secondary metabolites obtained from biosynthetic routes of certain fungi and are a group of toxic substances that are carcinogenic, neurotoxic, teratogenic and immunotoxic in nature (Zain 2011, FAO 2001, Petzinger \& Ziegler 2000). Several promising characteristics including low nutritional requirements, resistance to adverse environmental conditions, low or none toxicity to environment and the production of a large number of antifungal compounds are exhibited by Bacillus sp. isolated from soil (Ongena \& Jacques 2007, Pérez-García et al. 2011).

Various enzymes such as chitinases, glucanases and proteases are synthesized by Bacillus spp. which showed antagonistic activity against fungi and detoxify aflatoxins, the most toxic and potent hepatocarcinogenic mycotoxins produced by $A$. flavus; consisting several toxic compounds like sterigmatocystin, cyclopiazonic acid, kojic acid, nitropropionic acid, aspertoxin, aflatrem, gliotoxin, and aspergillic acid (Hedayati et al. 2007). Some research reported that Aflatoxin B1 could be degraded by Bacillus sp. isolated from fermented food (Petchkongkaew et al. 2008).

One hundred twenty confirmed deaths with $39.0 \%$ mortality rates were reported from Kenya due to aflatoxins (CDC, 2004). Researchers in Nepal have shown a presence of aflatoxins in foods and feeds (Kumar \& Yadav 2005, Desjardins et al. 2000). Furthermore, several neonatal exposures to aflatoxins have reported in the country. Therefore, finding an efficient and economical solution to deal with deleterious A. flavus has been a challenge to all the scientific communities of the world. Few researches regarding the Bacillus spp. producing amylase and exerting antifungal property have been done elsewhere in the country. In the light of this background, this study was aimed to isolate, screen and optimize thermo-tolerant Bacillus sp. showing high amylolytic and antifungal activity.

\section{MATERIALS AND METHODS}

\section{Collection of soil samples}

Thirty soil samples were collected aseptically during day time from different parts of Nepal including Janakpur, Khusibun, Illam, Sandakpur, Dhankuta and Begnas taal. About 100 gram of each soil samples was taken in polythene zip-lock bags with spatula and transported to the laboratory.

\section{Screening of amylolytic bacteria}

One gram of each soil samples was transferred to $50 \mathrm{~mL}$ sterile GYP broth in a conical flask for enrichment and incubated at $50^{\circ} \mathrm{C}$ for $3 \mathrm{~h}$. After enrichment, $1 \mathrm{~mL}$ solution was transferred into tube containing $9 \mathrm{ml}$ of sterile water, labeled and was mixed thoroughly. Serial dilution was performed up to $10^{-6}$ dilution. After each dilution, the tube was shaken well to make a homogenate sample. From the dilution $10^{-2}, 10^{-4}$ and $10^{-6}$ prepared earlier $0.1 \mathrm{ml}$ of dilution was surface plated on pre-poured starch yeast extract peptone (SYP) agar (0.5\% soluble starch, $0.5 \%$ yeast extract, $0.3 \%$ peptone, $0.5 \% \mathrm{NaCl}$ $1.5 \%$ agar). Spread plate technique was performed and plates were incubated at $50^{\circ} \mathrm{C}$ for $24 \mathrm{~h}$. The isolated colonies showing clear zone in the media were subcultured in SYP media in duplicate plate and incubated at $50^{\circ} \mathrm{C}$ for $24 \mathrm{~h}$. In one set of plates, iodine solution was flooded and zone of hydrolysis was observed.

\section{Identification of isolated microorganism}

The strain showing the maximum zone of clearance was then subjected to morphological (Gram and endospore staining) and biochemical test. The isolates were identified by performing catalase test, citrate test and Voges Proskaur test.

\section{Bacterial culture and enzyme fermentation}

Starter culture was prepared by adding a loopful of the strain into $5 \mathrm{~mL}$ of sterile SYP broth. It was mixed properly and incubated at $50^{\circ} \mathrm{C}$ for $24 \mathrm{~h}$. From this starter culture, $1 \mathrm{~mL}$ of suspension was aseptically transferred to $100 \mathrm{~mL}$ Erlenmeyer flask containing one gram of soluble starch in $100 \mathrm{~mL}$ Yeast Peptone broth. The flasks were then incubated at $50^{\circ} \mathrm{C}$ for 5 days.

\section{Determination of crude enzyme activity by augur cup plate method}

The activity of the extracellular enzyme was analyzed at an interval of every 24 hours up to 5 days of fermentation. About $1 \mathrm{~mL}$ of broth was pipetted into a sterile Eppendorf tube and refrigerated. After 5 days of fermentation, analysis of crude enzyme was done by augur cup plate method.

About $20 \mathrm{~mL}$ of sterile SYP media was poured on sterile petriplates. The media were allowed to cool. Four holes were made on each plate with sterile cork borer of $6 \mathrm{~mm}$ diameter. Then $50 \mu \mathrm{L}$ of the crude enzyme was added in each hole and the plates were incubated at $50^{\circ} \mathrm{C}$ for $24 \mathrm{~h}$. 
After incubation, iodine solution was poured on each plate. The zone of hydrolysis was observed and the diameter of each hydrolysis zone was noted for up to 5 days of fermentation. The strains showing highest zone of hydrolysis were selected for the optimization of the condition for enzyme production.

\section{Optimization of culture conditions for amylase production}

Bacillus isolates showing highest zone of hydrolysis were selected and the optimum growth characteristics of the isolate for the production of amylase were studied. The effect of temperature and $\mathrm{pH}$ on amylase production was studied.

\section{Effect of $\mathbf{p H}$ and temperature on amylase production}

The effect of $\mathrm{pH}$ on the enzyme activity was determined by preparing the media of different $\mathrm{pH}(5,5.5$ and 6$)$ in the Erlenmeyer flask. The $\mathrm{pH}$ of media was maintained by using $0.1 \mathrm{~N} \mathrm{HCl}$. The loopful of freshly culture $\left(50^{\circ} \mathrm{C}, 24\right.$ h) organism was inoculated in the SYP broth. The flask was incubated at two different temperatures $\left(35^{\circ} \mathrm{C}\right.$ and $50^{\circ} \mathrm{C}$ ). About $2.5 \mathrm{ml}$ of the suspension was pipetted out at every interval of $2 \mathrm{~h}$ and the process was repeated up to 6 h. The tube was centrifuged at $3000 \mathrm{rpm}$ for 15 minutes. The supernatant was transferred to new sterile tube. Acetone was then added till the volume becomes double. It was kept at $4^{\circ} \mathrm{C}$ in the refrigerator overnight. The content was centrifuged at $5000 \mathrm{rpm}$ for 5 minutes. The supernatant was discarded and the enzyme pellet was dissolved in small amount of phosphate buffer $(\mathrm{pH} 7)$. Thus obtained solution was taken as partially purified.

\section{DNS assay}

One $\mathrm{mL}$ of partially purified enzyme was added with 1 $\mathrm{mL}$ of $1 \%$ starch solution. The tubes were incubated at $50^{\circ} \mathrm{C}$ for 15 minutes then $1 \mathrm{~mL}$ of DNS reagent was added to stop the reaction. The tubes were kept in boiling water bath for 15-20 minutes or until red brown color developed. The solution was cooled and $10 \mathrm{~mL}$ distilled water was added. The blank solution was prepared by taking mixture of $2 \mathrm{~mL}$ distilled water and $1 \mathrm{~mL}$ DNS reagent. Ninety six well plates reader was used for DNS assay. The blank solution was used to calibrate the spectrophotometer. The absorbance of the mixture was observed at $540 \mathrm{~nm}$. The absorbance was used to determine the reducing sugar concentration and enzyme activity (Miller 1959, Bernfeld 1955).

\section{Isolation and screening of Aspergillus flavus}

Five different corn, maize and peanut samples were collected from the market randomly for the isolation of Aspergillus flavus using Potato dextrose agar. Phenotypic characteristics of isolates were confirmed by colony morphology. Aspergillus flavus differentiating medium
(ADM) was used to screen toxigenic A. flavus (orange color at the bases) (Bothast \& Fennell 1974).

\section{Test for antifungal activities}

An antifungal activity of the four isolates was performed by dual streaking method. Briefly, isolates DK9, DK10, IM4 and KD7 were inoculated perpendicularly on potato dextrose agar and a loopful inoculum of A. flavus was point inoculated at both sides of line $3 \mathrm{~cm}$ apart from Bacillus isolate. The Petri dishes were incubated at $30^{\circ} \mathrm{C}$ for 8 days, and then the areas of inhibition were measured. The antagonistic activity was evaluated according to the scale proposed by (Bacon \& Hinton 2002): - for no antagonism; + for weak antagonism (clear zones of inhibition $<3 \mathrm{~mm}$ ); ++ for moderate antagonism (clear zones of inhibition $\geq 3-9 \mathrm{~mm}$ ) and +++ for strong antagonism (clear zones of inhibition $>9 \mathrm{~mm}$ ).

\section{RESULTS}

\section{Isolation, screening and identification of isolates}

This study was carried out to isolate potent amylase producing Bacillus spp. from different soil samples. From 30 different soil samples, 29 isolates were obtained. On SYP agar, the characteristics of many isolates were moist, flat, irregular and slightly convex colonies. Most of the isolates were motile and catalase positive. All these isolates were amylase producers, Gram positive rods and spore formers (Table 1).

\section{Analysis of crude enzyme}

Figure 1 shows the amylase activity of 16 different isolates at different time interval. For isolates KA5, KD8 and SD11, the zone of hydrolysis obtained was found to be $6 \mathrm{~mm}, 10 \mathrm{~mm}$ and $8 \mathrm{~mm}$ after $24 \mathrm{~h}$, respectively. Similarly, the maximum amylase activity for KA1, SD12 and NC6 was $8 \mathrm{~mm}, 10 \mathrm{~mm}$ and $10 \mathrm{~mm}$ after $48 \mathrm{~h}$, respectively. Isolates IM3 and DK13 showed the maximum amylase activity after $72 \mathrm{~h}$. After $96 \mathrm{~h}$, isolates KD6, IM4, DK3 and DK10 showed $10 \mathrm{~mm}, 14 \mathrm{~mm}, 12$ $\mathrm{mm}$ and $12 \mathrm{~mm}$ zone of hydrolysis, respectively. Isolates KA2, KD7 and DK 9 showed the maximum amylase activity of $10 \mathrm{~mm}, 14 \mathrm{~mm}$ and $16 \mathrm{~mm}$, respectively, after $120 \mathrm{~h}$ of fermentation.

\section{Physiological and biochemical features of selected isolates}

From 16 different isolates, 4 isolates (DK9, DK10, IM4 and KD7) were selected that showed the highest amylolytic activity during augur cup plate method (Figs 1 and 2) and these isolates were subjected to physiological and biochemical tests (Table 2).

\section{Effect of $\mathrm{pH}$ and temperature on amylase production}

Total sugar concentration was estimated using standard calibration curve of glucose. As shown in Fig. 3(a), the 
reducing sugar concentration for isolates DK10, DK9, IM4 and KD7 were 93, 121, 107 and $121 \mathrm{mg} / \mathrm{L}$, respectively, after $6 \mathrm{~h}$ at $\mathrm{pH} 5$ and $35^{\circ} \mathrm{C}$. Figure 3(b) shows the reducing sugar concentration for isolates DK10, DK9, IM4 and KD7 as 53, 182, 159 and $295 \mathrm{mg} / \mathrm{L}$, respectively, after $6 \mathrm{~h}$ at $\mathrm{pH} 5$ and $50^{\circ} \mathrm{C}$. Similarly, Fig. 3(c) illustrates the reducing sugar concentration for isolates DK10, DK9, IM4 and KD7 as 136, 104, 132 and $127 \mathrm{mg} / \mathrm{L}$, respectively, after $6 \mathrm{~h}$ at $\mathrm{pH} 5.5$ and $35^{\circ} \mathrm{C}$.
Figure 3(d) describes the reducing sugar concentration for isolates DK10, DK9, IM4 and KD7 as 176, 213, 187 and $211 \mathrm{mg} / \mathrm{L}$, respectively, after $6 \mathrm{~h}$ at $\mathrm{pH} 5.5$ and $50^{\circ} \mathrm{C}$. Figure 3(e) illustrates the reducing sugar concentration for isolates DK10, DK9, IM4 and KD7 as 226, 213, 172 and $228 \mathrm{mg} / \mathrm{L}$, respectively, after $6 \mathrm{~h}$ at $\mathrm{pH} 6$ and $35^{\circ} \mathrm{C}$. Figure 4(f) shows the reducing sugar concentration for isolates DK10, DK9, IM4 and KD7 as 312, 467, 323 and $523 \mathrm{mg} / \mathrm{L}$, respectively, after $6 \mathrm{~h}$ at $\mathrm{pH} 6$ and $50^{\circ} \mathrm{C}$.

Table 1. Morphological characteristics of isolates

\begin{tabular}{|c|c|c|c|c|c|}
\hline $\begin{array}{l}\text { Soil sample } \\
\text { location }\end{array}$ & Isolate & Gram staining & $\begin{array}{l}\text { Endospore } \\
\text { staining }\end{array}$ & Catalase test & $\begin{array}{l}\text { Tentatively identified } \\
\text { genus }\end{array}$ \\
\hline \multirow[t]{6}{*}{ Khushibu } & KA1 & Gram Positive & Central & Positive & Bacillus \\
\hline & KA2 & Gram Positive & Central & Positive & Bacillus \\
\hline & KA5 & Gram Positive & Sub-terminal & Positive & Bacillus \\
\hline & KD6 & Gram Positive & Central & Positive & Bacillus \\
\hline & KD7 & Gram Positive & Sub-terminal & Positive & Bacillus \\
\hline & KD8 & Gram Positive & Central & Positive & Bacillus \\
\hline \multirow[t]{3}{*}{ Illam } & IM3 & Gram Positive & Central & Positive & Bacillus \\
\hline & IM4 & Gram Positive & Sub-terminal & Positive & Bacillus \\
\hline & IM8 & Gram Positive & Central & Positive & Bacillus \\
\hline \multirow[t]{3}{*}{ Sandakpur } & SD9 & Gram Positive & Sub-terminal & Positive & Bacillus \\
\hline & SD11 & Gram Positive & Sub-terminal & Positive & Bacillus \\
\hline & SD12 & Gram Positive & Central & Positive & Bacillus \\
\hline \multirow[t]{4}{*}{ Dhankuta } & DK3 & Gram Positive & Central & Positive & Bacillus \\
\hline & DK9 & Gram Positive & Central & Positive & Bacillus \\
\hline & DK10 & Gram Positive & Sub-terminal & Positive & Bacillus \\
\hline & DK13 & Gram Positive & Sub-terminal & Positive & Bacillus \\
\hline \multirow[t]{2}{*}{ Nuwakot } & $\mathrm{NC} 4$ & Gram Positive & Sub-terminal & Positive & Bacillus \\
\hline & NC6 & Gram Positive & Central & Positive & Bacillus \\
\hline \multirow[t]{11}{*}{ Janakpur } & $\mathrm{J} 1$ & Gram Positive & Central & Positive & Bacillus \\
\hline & $\mathrm{J} 2$ & Gram Positive & Central & Positive & Bacillus \\
\hline & $\mathrm{J} 3$ & Gram Positive & Sub-terminal & Positive & Bacillus \\
\hline & $\mathrm{J} 4$ & Gram Positive & Central & Positive & Bacillus \\
\hline & $\mathrm{J} 5$ & Gram Positive & Central & Positive & Bacillus \\
\hline & $\mathrm{J} 7$ & Gram Positive & Sub-terminal & Positive & Bacillus \\
\hline & $\mathrm{J} 8$ & Gram Positive & Sub-terminal & Positive & Bacillus \\
\hline & $\mathrm{J} 11$ & Gram Positive & Sub-terminal & Positive & Bacillus \\
\hline & $\mathrm{J} 12$ & Gram Positive & Central & Positive & Bacillus \\
\hline & $\mathrm{J} 14$ & Gram Positive & Central & Positive & Bacillus \\
\hline & $\mathrm{J} 16$ & Gram Positive & Sub-terminal & Positive & Bacillus \\
\hline
\end{tabular}




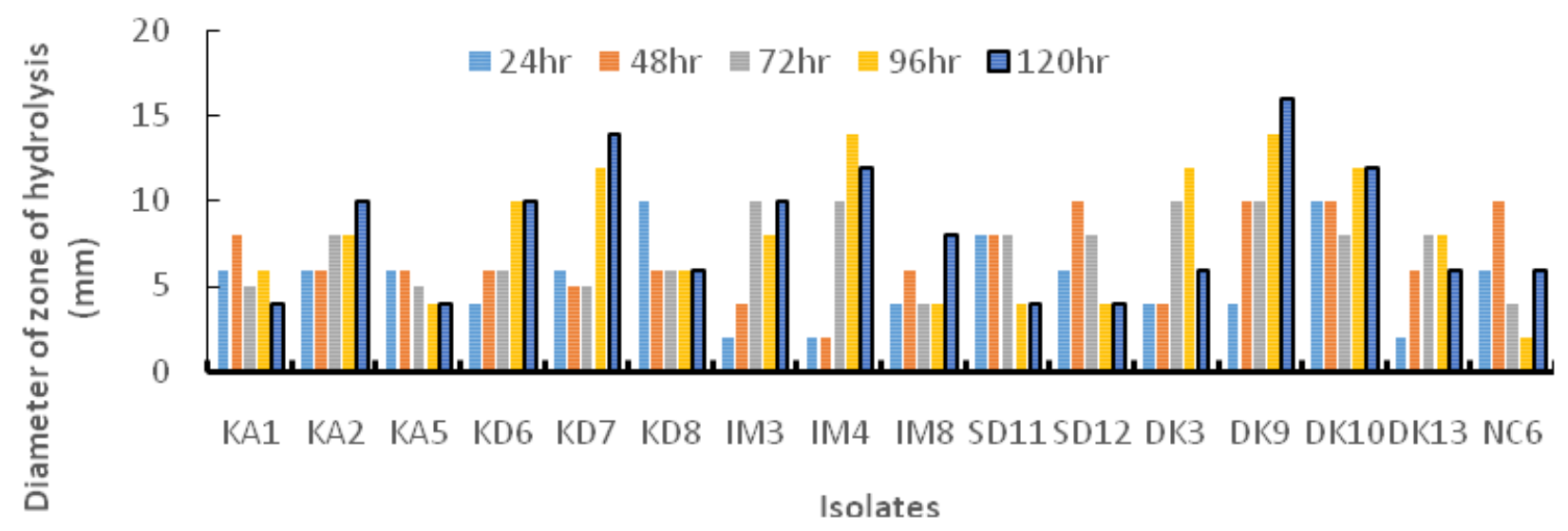

Fig. 1. Diagram showing zone of hydrolysis by the isolates

Table 2. Physiological and biochemical test of isolates

\begin{tabular}{|c|c|c|c|c|c|c|c|}
\hline $\begin{array}{c}\text { Strain } \\
\text { code }\end{array}$ & $\begin{array}{c}\text { Gram } \\
\text { reaction }\end{array}$ & Endospore & Catalase & $\begin{array}{c}\text { Voges } \\
\text { Proskauer }\end{array}$ & $\begin{array}{c}\text { Citrate } \\
\text { utilization }\end{array}$ & $\begin{array}{c}\text { Growth } \\
\text { at } \mathbf{6 0} \text { C }\end{array}$ & $\begin{array}{c}\text { Probable } \\
\text { identified }\end{array}$ \\
\hline DK9 & + & + & + & + & - & - & Bacillus spp. \\
\hline DK10 & + & + & + & + & + & + & Bacillus spp. \\
\hline IM4 & + & + & + & + & + & + & Bacillus spp. \\
\hline KD7 & + & + & + & + & + & + & Bacillus spp. \\
\hline
\end{tabular}

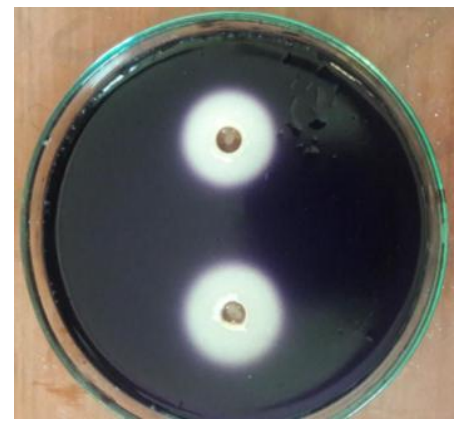

Fig. 2. Amylolytic activity of an isolate KD7 (volume 50 $\mu \mathrm{L}$, incubation time and temperature $24 \mathrm{~h}$ and $50^{\circ}$ C)

\section{Determination of amylase activity}

Table 3 shows enzyme activity of different isolates at $35^{\circ}$ $\mathrm{C}$ and different incubation time $(2 \mathrm{~h}, 4 \mathrm{~h}$ and $6 \mathrm{~h})$. The amylase activity of isolates DK10, DK9, IM4 and KD7 was maximum $(0.08,0.07,0.06$ and $0.08 \mathrm{U} / \mathrm{mL})$ at $6 \mathrm{~h}$ of fermentation and at $\mathrm{pH}$ 6. Similarly, Table 4 shows enzyme activity of different isolates at $50^{\circ} \mathrm{C}$ and different incubation time $(2 \mathrm{~h}, 4 \mathrm{~h}$ and $6 \mathrm{~h})$. The amylase activity of isolates DK10, DK9, IM4 and KD7 was maximum (0.11, $0.17,0.12$ and $0.19 \mathrm{U} / \mathrm{mL}$ ) at $6 \mathrm{~h}$ of fermentation and at pH 6. DK 9 and KD7 exhibited high antagonistic activity while both INP4 and DK10 showed moderate antagonistic activity against $A$. flavus as shown in Figs 4(a) and 4(b).

Table 3. Enzyme activity at $35^{\circ} \mathrm{C}$

\begin{tabular}{|c|c|c|c|c|c|c|c|c|c|c|c|c|}
\hline \multirow[t]{4}{*}{ pH } & \multicolumn{12}{|c|}{ Isolates } \\
\hline & \multicolumn{3}{|c|}{ DK10 } & \multicolumn{3}{|c|}{ DK9 } & \multicolumn{3}{|c|}{ IM4 } & \multicolumn{3}{|c|}{ KD7 } \\
\hline & \multicolumn{12}{|c|}{ Enzyme activity (U/mL) after different time intervals } \\
\hline & $2 \mathrm{~h}$ & $4 \mathrm{~h}$ & $6 \mathrm{~h}$ & $2 \mathrm{~h}$ & $4 \mathrm{~h}$ & $6 \mathrm{~h}$ & $2 \mathrm{~h}$ & $4 \mathrm{~h}$ & $6 \mathrm{~h}$ & $2 \mathrm{~h}$ & $4 \mathrm{~h}$ & $6 \mathrm{~h}$ \\
\hline 5.0 & 0.03 & 0.02 & 0.03 & 0.03 & 0.03 & 0.04 & 0.02 & 0.03 & 0.04 & 0.04 & 0.04 & 0.04 \\
\hline 5.5 & 0.06 & 0.05 & 0.05 & 0.04 & 0.06 & 0.04 & 0.03 & 0.04 & 0.05 & 0.06 & 0.04 & 0.04 \\
\hline 6.0 & 0.07 & 0.06 & 0.08 & 0.06 & 0.03 & 0.07 & 0.05 & 0.05 & 0.06 & 0.04 & 0.05 & 0.08 \\
\hline
\end{tabular}




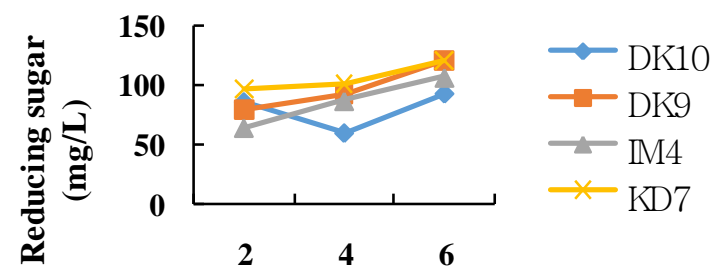

Time (h)

(a)

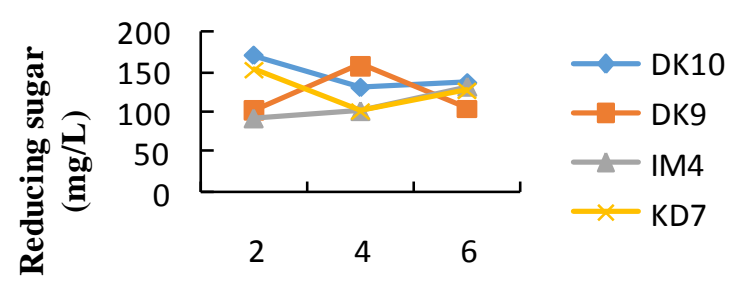

Time (h)

(c)

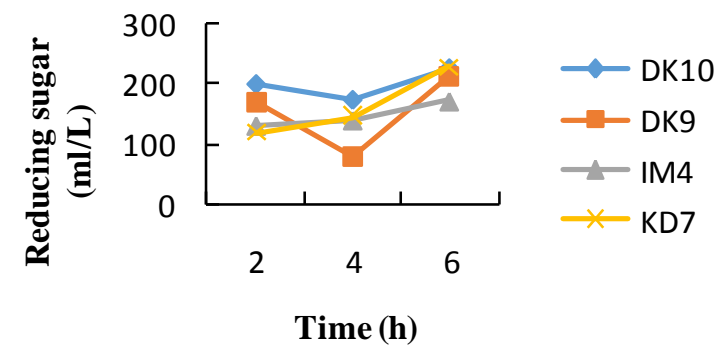

(e)

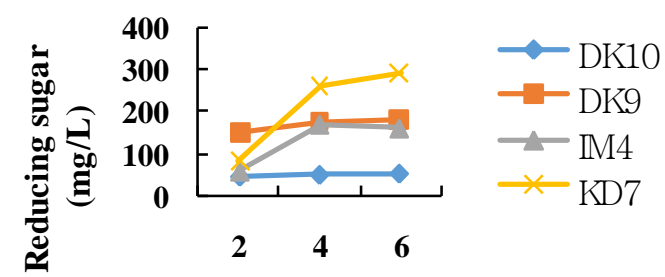

Time (h)

(b)

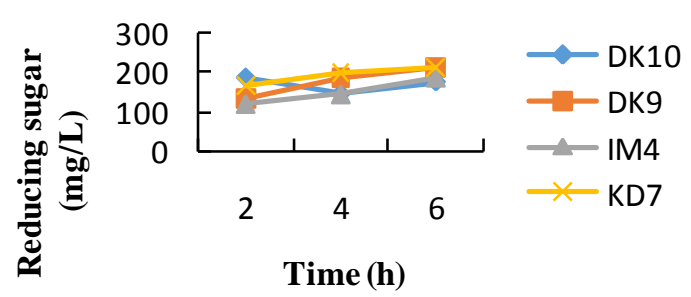

(d)

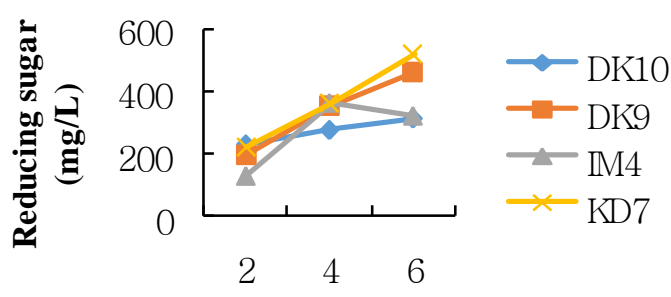

Time (h)

(f)

Fig. 3. Reducing sugar concentration at (A) pH 5.0 and $35^{\circ} \mathrm{C},(\mathrm{B}) \mathrm{pH} 5.0$ and $50^{\circ} \mathrm{C},(\mathrm{C}) \mathrm{pH} 5.5$ and $35^{\circ} \mathrm{C}$, (D) $\mathrm{pH} 5.5$ and $50^{\circ} \mathrm{C}$, (E) pH 6.0 and $35^{\circ} \mathrm{C}$ and (F) pH 6.0 and $50^{\circ} \mathrm{C}$

Table 4. Enzyme activity at $50^{\circ} \mathrm{C}$

\begin{tabular}{|c|c|c|c|c|c|c|c|c|c|c|c|c|}
\hline \multirow[t]{4}{*}{ pH } & \multicolumn{12}{|c|}{ Isolates } \\
\hline & \multicolumn{3}{|c|}{ DK10 } & \multicolumn{3}{|l|}{ DK9 } & \multicolumn{3}{|l|}{ IM4 } & \multicolumn{3}{|l|}{ KD7 } \\
\hline & \multicolumn{12}{|c|}{ Enzyme activity $(\mathrm{U} / \mathrm{mL})$ after different time intervals } \\
\hline & $2 \mathrm{~h}$ & $4 \mathrm{~h}$ & $6 \mathrm{~h}$ & $2 \mathrm{~h}$ & $4 \mathrm{~h}$ & $6 \mathrm{~h}$ & $2 \mathrm{~h}$ & $4 \mathrm{~h}$ & $6 \mathrm{~h}$ & $2 \mathrm{~h}$ & $4 \mathrm{~h}$ & $6 \mathrm{~h}$ \\
\hline 5.0 & 0.02 & 0.02 & 0.02 & 0.05 & 0.06 & 0.07 & 0.02 & 0.06 & 0.06 & 0.03 & 0.09 & 0.10 \\
\hline 5.5 & 0.07 & 0.05 & 0.05 & 0.06 & 0.07 & 0.08 & 0.04 & 0.05 & 0.07 & 0.06 & 0.07 & 0.08 \\
\hline 6.0 & 0.08 & 0.10 & 0.11 & 0.07 & 0.13 & 0.17 & 0.05 & 0.09 & 0.12 & 0.08 & 0.13 & 0.19 \\
\hline
\end{tabular}


Table 5. Primary screening of Bacillus sp. for the growth inhibition of Aspergillus flavus

\begin{tabular}{|c|c|c|}
\hline $\begin{array}{l}\text { Bacterial } \\
\text { isolates }\end{array}$ & $\begin{array}{l}\text { Antagonism } \\
\text { (After } 8 \text { days } \\
\text { incubation) }\end{array}$ & Inference \\
\hline DK9 & ++++ & Strong antagonism \\
\hline DK10 & ++ & $\begin{array}{l}\text { Moderate } \\
\text { antagonism }\end{array}$ \\
\hline IMP4 & ++ & $\begin{array}{l}\text { Moderate } \\
\text { antagonism }\end{array}$ \\
\hline KD7 & ++++ & Strong antagonism \\
\hline
\end{tabular}

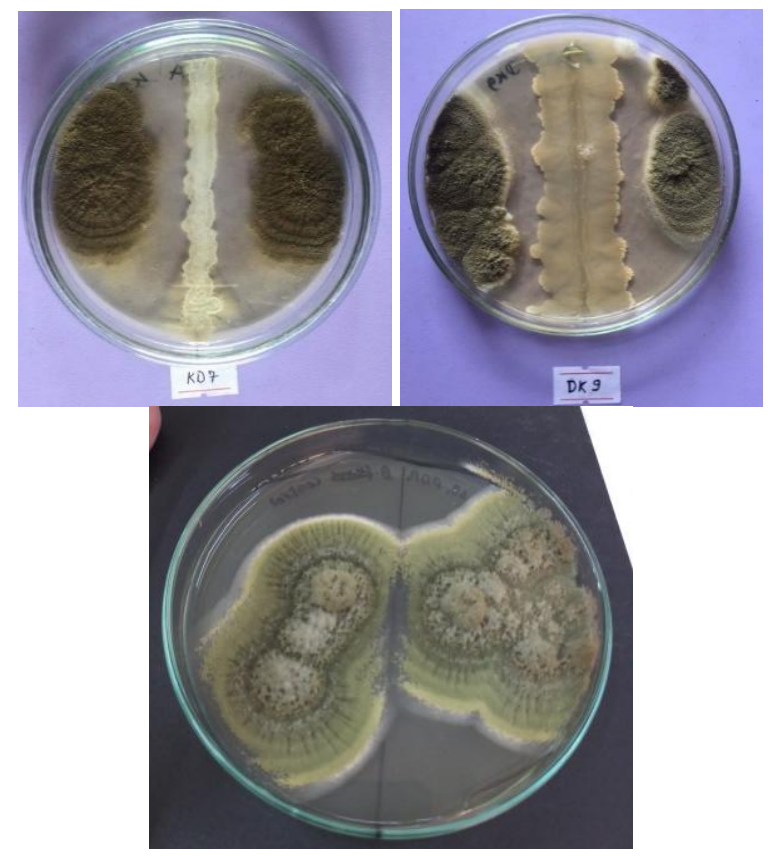

Fig. 4. KD7 inhibiting the growth of A. flavus, DK9 inhibiting the growth of A. flavus

\section{DISCUSSION}

In this study, 30 soil samples were collected from different locations. From these soil samples, 29 isolates were identified as Bacillus spp. from cultural and morphological characteristics and they were found to be Gram positive spore forming rod shaped bacteria (Singh et al. 2015). Among different bacterial isolates, best 16 isolates were selected and screened for the production of amylase. SYP agar was used and iodine solution was flooded to observe the clear zone of hydrolysis. The formation of clear zone was due to degradation of starch by amylase produced by Bacillus isolates. Starch in the medium turned blue as the iodine was trapped in the helical structure of starch but the monosaccharide cannot bind the iodine molecule and became colorless. Forgarty and Kelly (1979) and Iverson and Millis (1974) reported that the starch nutrient agar and iodine can be used for detecting amylase (hydrolytic enzyme) producing microorganisms that can hydrolyze starch forming clear zone surrounding an area of colony.

On the basis of maximum diameter of clear zone formation, 4 isolates (DK9, DK10, IM4 and KD7) were selected for further study. These isolates were purified by sub culturing the colonies on SYP agar for 3 to 4 times. These colonies were further incubated at $60^{\circ} \mathrm{C}$. Three isolates (DK9, IM4 and KD7) were found to grow at this temperature. This indicates that these isolates might elicit the amylolytic activity even at $60^{\circ} \mathrm{C}$, which requires further studies. Al-Johani et al. (2017) reported a thermotolerant B. subtilis isolated from hot-spring water with potent amylase producing capability.

Temperature and $\mathrm{pH}$ are the two factors that greatly affect the amylase activity (Poudel et al. 2015, Saha \& Mazumdhar 2019, Swain \& Ray 2007). Partially purified enzymes produced by these isolates were assayed at varying $\mathrm{pH}(5.0,5.5$ and 6.0$)$ and temperature $\left(35^{\circ} \mathrm{C}\right.$ and $\left.50^{\circ} \mathrm{C}\right)$. The reducing sugar concentration was determined at 2,4 and $6 \mathrm{~h}$ of incubation according to the dinitrosalycyclic method (Miller 1959, Bernfeld 1955). The concentration of reducing sugar was found to be maximum after $6 \mathrm{~h}$ of incubation. The concentration of reducing sugar was augmented with the increase in fermentation time. A high concentration of reducing sugar indicates high production of amylase by the isolates at that time period. The amylase activity was relatively greater at pH $6.0(0.19 \mathrm{U} / \mathrm{mL})$ given by isolate KD7. The enzyme activity was found to decrease with decreased in $\mathrm{pH}$ of the media. This indicated that high acidic condition is not suitable for the amylase production. This finding was supported by Singh et al. (2015) who verified that acidic environment is not appropriate for higher yield of enzyme.

In this study, 16 Bacillus spp. showing amylolytic activity were isolated from soil samples. All these isolates were able to grow at $50^{\circ} \mathrm{C}$, showing thermo-tolerant in nature. Among these isolates, KD7, DK9, DK10 and IM4 (14 $\mathrm{mm}, 16 \mathrm{~mm}, 12 \mathrm{~mm}$ and $14 \mathrm{~mm}$ zone of hydrolysis) were found to be potent amylase producer. KD7 showed the highest amylolytic activity $(0.19 \mathrm{U} / \mathrm{mL})$ compared to other isolates. The amylase activity was relatively greater at $50^{\circ} \mathrm{C}$ than $35^{\circ} \mathrm{C}$ which indicates that amylases are active at high temperature and thermophilic temperature is suitable for amylase production. Hence, the optimum $\mathrm{pH}$ was 6.0 and optimum temperature was $50^{\circ} \mathrm{C}$ for amylase activity. Our research is consistent with work done by Femi-Ola and Olowe (2011) who reported that amylase produced by Bacillus subtilis BS5 had a molecular weight of $63 \mathrm{kDa}$ and was optimally active at $\mathrm{pH} 6.0$ and $50^{\circ} \mathrm{C}$. However, Singh et al. (2015) showed that $\mathrm{pH} 7$ and $40^{\circ} \mathrm{C}$ temperature were optimum values for growth of isolates and maximum amylase production by Bacillus spp. These 
differences in result may have occurred due to the difference in media composition used, site of sample collection and incubation period. Furthermore, the size of inoculum used also affects enzyme activity. Nadia et al. (2003) reported that the production of the amylases slowdown as the inoculum size was increased because the growth of the organism was considerably amplified and the nutrients present in the medium were insufficient to overcome the growth of organisms. Similarly, growth of microorganism also decreased at low inoculum level as the time to reach stationary phase by organisms increased during their growth.

Our study revealed that DK 9 and KD7 exhibited high antagonistic activity while both IM4 and DK10 showed moderate antagonistic activity against A. flavus. Some studies showed that Bacillus spp. can produce lipopeptides with capability to impede fungal growth (Chen et al. 2009, Zhao et al. 2010). Similarly, a research conducted by Veras et al. 2016 showed that some Bacillus spp. isolated from fish intestine inhibited A. flavus and other mycotoxin producing fungi along with the detoxification of aflatoxins and other mycotoxins. Thakaew and Niamsup (2013) and Mnif and Ghribi (2015) showed that Bacillus spp. are potent producers of antifungal proteins, including enzymes such as chitinases, glucanases and proteases that can effectively inhibit the detrimental fungi and their mycotoxins.

\section{CONCLUSION}

Our study revealed, thermotolerant Bacillus spp. KD7, DK9, DK10 and IM4 were found to be potent amylase producer amongst which KD7 showed highest amylolytic activity compared to other isolates. The optimum $\mathrm{pH}$ and temperature for amylase production was found to be 6.0 and $50^{\circ} \mathrm{C}$, respectively. Furthermore, antifungal activities shown by KD7 and DK9 indicated that these bacteria can be used as effective bio-control agents against toxigenic A. flavus. Hence, further strain selection and identification would pave the way for commercial enzyme production as well as search for a potent antifungal agent.

\section{REFERENCES}

Afrisham, S., Badoei-dalfard, A. and Namaki-shoushtari, A. 2016. Enzymatic characterization of a thermostable , $\mathrm{CaCl}_{2}$-activated and raw-starch hydrolyzing alpha-amylase from Bacillus licheniformis AT70: Production under solid state fermentation by utilizing agricultural wastes. Journal of Molecular Catalysis-B, Enzymatic 132: 98-106.

Aiba, S., Kitai, K . and Imanaka, T. 1983. Cloning and expression of thermostable alpha-amylase gene from Bacillus stearothermophilus in Bacillus stearothermophilus and Bacillus subtilis. Applied and Environmental Microbiology 46(5): 1059-1065.
Aiyer, P.V. 2005. Amylases and their applications. African Journal of Biotechnology 4(13): 1525-1529.

Al-Johani, N.B., Al-seeni, M.N., Ahmed, Y.M. 2017. Optimization of alkaline $\alpha$-amylase production by thermophilic Bacillus subtilis. African Journal of Traditional Complementary and Alternative Medicines 14(1): 288-301.

Azad, M.A.K., Bae, J.H., Kim, J.S., Lim, J.K., Song, K.S., Shin, B.S. and Kim, H.R. 2009. Isolation and characterization of a novel thermostable $\alpha$-amylase from Korean pine seeds. New Biotechnology 26(34): 143-149.

Bacon, C.W. and Hinton, D.M. 2002. Endophytic and biological control potential of Bacillus mojavensis and related species. Biological Control 23(3): 274284.

Bernfeld, P. 1955. Amylases, $\alpha$ and $\beta$. Methods in Enzymology 1: 149-158.

Bothast, J.R. and Fennell, D.I. 1974. A medium for rapid identification and enumeration of Aspergillus flavus and related organisms. Mycologia 66 (2): 365-369.

Boyer, E.W. and Ingle, M.B. 1972. Extracellular alkaline amylase from a Bacillus species. Journal of Bacteriology 110(3): 992-1000.

Burhan, A., Nisa, U., Gökhan, C., Ömer, C., Ashabil, A. and Osman, G. 2003. Enzymatic properties of a novel thermostable, thermophilic, alkaline and chelator resistant amylase from an alkaliphilic Bacillus spp. isolate ANT-6. Process Biochemistry 38(10): 1397-1403.

CDC 2004. Outbreak of aflatoxin poisoning- eastern and central provinces, Kenya. Centers for Disease Control and Prevention, MMWR September 3 53(34): 790-793.

Chen, X.H., Koumoutsi, A., Scholz, R., Schneider, K., Vater, J., Süssmuth, R. and Borriss, R. 2009. Genome analysis of Bacillus amyloliquefaciens FZB42 reveals its potential for biocontrol of plant pathogens. Journal of Biotechnology 140 (1-2): $27-$ 37.

Cordeiro, C.A.M., Martins, M.L.L. and Luciano, A.B. 2002. Production and properties of alpha-amylase from thermophilic Bacillus spp. Brazilian Journal of Microbiology 33(1): 57-61.

Desjardins, A.E., Manandhar, G., Plattner, R.D., Maragos, C.M., Shrestha, K. and Mccormick, S.P. 2000. Occurrence of Fusarium species and mycotoxins in Nepalese maize and wheat and the effect of traditional trocessing methods on mycotoxin Levels. Journal of Agriculture and Food Chemistry 48(4): 
1377-83.

FAO. 2001. Manual on the application of the HACCP system in mycotoxin prevention and control. FAO Food and Nutrition Paper 73, pp. 124.

Femi-Ola, T.O. and Olowe, B.M. 2011. Characterization of alpha- amylase from Bacillus subtilis BS5 isolated from Amitermes evuncifer silvestr. Research Journal of Microbiology 6(2): 140-146.

Forgarty, W. and Kelly, C. 1979. Starch degrading enzymes of microbial origin. Journal of Progress in Industrial Microbiology 15: 87-150.

Fossi, B.T., Tavea, F., Fontem, L.A., Ndjouenkeu, R. and Wanji, S. 2014. Microbial interactions for enhancement of $\alpha$-amylase production by Bacillus amyloliquefaciens 04BBA15 and Lactobacillus fermentum 04BBA19. Biotechnology Reports 4(1): 99-106.

Hedayati, M.T., Pasqualotto, A.C., Warn, P.A., Bowyer, P. and Denning, D.W. 2007. Aspergillus flavus: Human pathogen, allergen and mycotoxin producer. Microbiology 153: 1677-1692.

Iverson, W. and Millis. N. 1974. A method for the detection of starch hydrolysis by bacteria. Journal of Applied Bacteriology 37: 443-446.

Kathiresan, K. and Manivannan, S. 2006. $\alpha$-Amylase production by Penicillium fellutanum isolated from mangrove rhizosphere soil. African Journal of Biotechnology 5(10): 829-832.

Kumar, S. and Yadav, B. 2005. Occurrence of aflatoxin in some of the food and feed in Nepal. Indian Journal of Medical Sciences 59(8): 331-336.

Lin, L.-L., Hsu, W.-H. and Chu, W.-S. 1997. A gene encoding for an $\alpha$-amylase from thermophilic Bacillus spp. strain TS-23 and its expression in Escherichia coli. Journal of Applied Microbiology 82(3): 325-334.

Manif, I. and Ghribi, D. 2015. Potential of bacterial derived biopesticides in pest management. Crop Protection 77: 52-64.

Miller, G.L. 1959. Use of dinitrosalicylic acid reagent for determination of reducing sugar. Analytical Chemistry 31(3): 426-428.

Nadia, R., Haq, I. and Qadeer, M.A. 2003. Characterization of $\alpha$-amylase by Bacillus subtilis. International Journal of Agriculture and Biology 5(3): 249-252

Ongena, M. and Jacques, P. 2008. Bacillus lipopeptides : versatile weapons for plant disease biocontrol. Trends in Microbiology 16(3): 115-125.
Pandey, A., Nigam, P., Soccol, C.R., Soccol, V.T., Singh, D. and Mohan, R. 2000. Advances in microbial amylases. Biotechnology and Applied Biochemistry 31: $135-152$.

Perez-Garcia, A., Romero, D. and de Vicente A. 2011. Plant protection and growth stimulation by microorganisms: biotechnological applications of Bacilli in agriculture. Current Opinion in Biotechnology 22(2): 187-193.

Petchkongkaew, A., Taillandier P., Gasaluck P. and Lebrihi A. 2008. Isolation of Bacillus spp. from Thai fermented soybean (Thua-nao): screening for aflatoxin B1 and ochratoxin A detoxification. Journal of Applied Microbiology 104 (5): 14951502.

Petzinger, E. and Ziegler, K. 2000. Ochratoxin A from a toxicological perspective. Journal of Veterinary Pharmacology and Therapeutics 23(2): 91-98.

Pokhrel, B., Wanjare, P., Singh, S., Purushotam, B. and Kumara S.M. 2013. Isolation, screening and characterization of promising $\alpha$-amylase producing bacteria from sewage enriched soil. International Journal of Advanced Biotechnology and Research 4(2): 286-290.

Poudel, P., Yukihiro T., Miyamoto, H. Miyamoto, H., Okugawa, Y. and Sakai, K.. 2015. Direct starch fermentation to L-lactic acid by a newly isolated thermophilic strain, Bacillus sp. MC-07. Journal of Industrial Microbiology and Biotechnology 42: 143149.

Saha, S.P. and Mazumdar, D. 2019. Optimization of process parameter for alpha-amylase produced by Bacillus cereus amy3 using one factor at a time (OFAT), and central composite rotatable (CCRD) design based response surface methodology (RSM). Biocatalysis and Agricultural Biotechnology 19: 101168.

Singh, V., Sharma, R. and Sharma, P. 2015. Isolation, screening and optimization of amylase producing Bacillus spp . from soil. Asian Pacific Journal of Health Science 2(3): 94-103.

Swain, M.R. and Ray, R.C. 2007. Alpha-amylase production by Bacillus subtilis CM3 in solid state fermentation using cassava fibrous residue. Journal of Basic Microbiology 47: 417-425.

Thakaew, R. and Niamsup, H. 2013. Inhibitory activity of Bacillus subtilis BCC 6327 metabolites against growth of Aflatoxigenic fungi isolated from bird Chili Powde. International Journal of Bioscience, Biochemistry and Bioinformatics 3(1): 3-8.

Veras, F.F., Correa, A.P.F., Welke, J.E. and Brandelli, A. 
Screening and optimization of thermo-tolerant Bacillus spp. for amylase production....

2016. Inhibition of mycotoxin-producing fungi by Bacillus strains isolated from fish intestines. International Journal of Food Microbiology 238: 23-32.

Zain, M.E. 2011. Impact of mycotoxins on humans and animals. Journal of Saudi Chemical Society 15(2):
129-144.

Zhao, Z., Wang, Q., Wang, K., Brian, K., Liu, C. and Gu, Y. 2010. Bioresource technology study of the antifungal activity of Bacillus vallismortis ZZ185 in vitro and identification of its antifungal components. Bioresource Technology 101(1): 292-297. 